\section{Evaluation of Public Libraries in India: the case of Karnataka}

Despite the importance of public libraries in many developing countries, there have been few attempts to evaluate their effectiveness.

\section{James Heitzman and A.Y. Asundi}

\section{INTRODUCTION}

Public libraries in the so-called developing countries are among the most extensive publicly-funded information infrastructures in the world, reaching large numbers of users with sources on contemporary events, career improvement, technical instruction and entertainment. There has been little effort to evaluate the effectiveness of these libraries, to critique the expressed or tacit models implemented in planning of their service provision, or to understand the relationship between patterns of service delivery and the social characteristics of their targeted users. This article is a discussion of the public library system in Karnataka, a rather typical state in southern India. ${ }^{1}$ The purpose of the article is to provide an empirical description of the system's structure and its clientele, to present methodologies implemented to evaluate the system in the 1990s, and to discuss the effectiveness of the system in service provision and planning.

Until Independence in 1947, most of Karnataka fell under the independent princely state of Mysore, an autocratic monarchy that allowed its technocratic bureaucracy considerable freedom to implement modern, industrial planning models and to establish some of India's earliest electrification and communication infrastructures. In 1956, with the linguistic reorganization of Indian states, Mysore expanded its boundaries and adopted Kannada as its official language, and in the 1960s adopted its current name. One of the most spectacular and well-known features of subsequent economic change was the explosive growth of the state capital, Bangalore, which became the sixth largest Indian city (the population of the metropolitan agglomeration was $4,130,288$ in 1991). As the site of extensive industrial production in textiles, machinery and electrical equipment, and as the home of the state administration, Bangalore was well positioned to move into software production that gave it the reputation as 'India's Silicon Valley' in the 1990s. ${ }^{2}$ Here a large middle class of technicians and professionals lived alongside a large working class population with jobs in the formal sector, but a majority of the working population still labored in the informal sector while a growing proportion of the city's population lived in slums. ${ }^{3}$ Located in the southeastern corner of Karnataka, near the intersection of four south Indian states, cosmopolitan Bangalore included substantial linguistic minorities speaking Hindi/Urdu, Tamil, Telugu, Malayalam and Marathi. Despite a powerful pro-Kannada movement that informed official policy in the state, English remained an important language for technical and professional disciplines and was well-known by upper-class citizens. The literacy rate in the state as a whole in 1996 was 63.42 percent, but in Bangalore it was 83.61 percent. ${ }^{4}$ The challenges facing the public library system thus included marked class differences, a multiplicity of language constituencies, and a pronounced divide between rural and urban areas.

Recommendations of Mysore Prime Minister M. Visveswaraya led to the establishment in 1914 of the first public libraries in Mysore, the seat of the king, and in Bangalore, already the state's main city. The Mysore Library Association was registered as a society in 1929, and the next year supported Dr. S.R. Ranganathan's preparation of a model bill for the establishment of state-run public library systems in India. In 1949, the first state library department came into existence in the neighboring state of Madras (now Tamil Nadu), establishing a precedent for state direction of public libraries that remains typical in most of India today. The modern history of public libraries in the state of Mysore began with passage of the 1965 Mysore Public Libraries Act (its name changed to the Karnataka Public Libraries Act in 1973). The law mandated the establishment of a State Department of Public Libraries, city library authorities in all towns with populations greater than 100,000, and district library authorities in all district headquarters within the state. The city of Bangalore was divided into five zones (north, east, west, south and center), each containing a main zonal library and a number of branch libraries and small service centers). The public library in Bangalore became the State Central Library, the coordinating point for inter-library loan and technical services, the state library for the blind, and the repository for three copies of each book published in the state including the Karnataka State Gazette. Funding for books and supplies came from stipulated state taxes and salaries for staff, who as members of the State Library Service were government employees, came from a separate personnel budget in the consolidated fund of the state. The Karnataka State Department of Public Libraries began to function in November 1966 and registered steady growth for thirty-five years. Between 1983 and 1999, membership increased by over 400 percent, library sites by almost 500 percent, and book holdings by almost 400 percent (See Table 1). ${ }^{5}$

\begin{tabular}{|l|r|r|r|}
\hline System features & \multicolumn{1}{|c|}{1981} & \multicolumn{1}{c|}{$1993-94$} & \multicolumn{1}{c|}{1999} \\
\hline Members & 135,000 & 401,989 & 654,430 \\
\hline Staff & 939 & 1,060 & 1,235 \\
\hline Sites & 389 & 1,332 & 1,922 \\
\hline Journals & 9,490 & 18,162 & 18,162 \\
\hline Books & $2,500,000$ & $7,000,000$ & $8,700,000$ \\
\hline
\end{tabular}

Table 1. Expansion of the Karnataka State Public Library System.

\section{EVALUATING PUBLIC LIBRARIES IN INDIA}

Until the late 1980s, few structured efforts had evaluated the overall performance of the state public library systems in India. Analysis consisted of descriptions of the additional num- 
bers of buildings, books, users and staff added over the period of a year or a decade, with the assumption that larger numbers automatically meant increasing efficiency. A more critical look at the public library system as a whole came from H.A. Khan, who described the 'typical growth features' of the systems since independence as (1) an urban orientation, with less effort expended on penetration in rural villages; $(2)$ a concentration on print media; (3) a push toward quantitative growth in the number of buildings or size of collections, with little concern for the quality or relevance of the holdings; (4) an orientation toward recreational reading rather than the practical research interests of the client population; (5) a tendency to focus on housekeeping operations rather than engaging in outreach to the community; (6) little contact with the social needs of the environment. The author pointed out the need for linkage between the library centers and local development processes. In his earlier work on Karnataka and three other South Indian states, the author noted that the levels of funding legislated for the public libraries remained inadequate for attaining the minimum standards recommended by the International Federation of Library Associations and Institutions (IFLA), but that the first steps in remedying disjunctions between extant services and user needs must include surveys of library users and non-users, in both rural and urban locations. ${ }^{6}$

A preliminary effort at surveying the performance of public libraries took place in Tamil Nadu, where researchers utilized a time series of collection and membership records along with census data to gauge the effectiveness of services. ${ }^{7}$ Subsequently there was a preliminary survey of users in the library system in Bangalore, which investigated membership records in eight sites in the south zone, including the zonal library, two branches, and five service centers. ${ }^{8}$ The demographic profile of users revealed that the largest group ( 35 percent) were between 16 and 25 years of age, and that 58 percent of users had reached an education level of SSLC (Secondary School Leaving Certificate, obtained after finishing tenth standard) or below. Students comprised 56 percent of users, housewives 12 percent, and government employees 8.3 percent. There was an uneven distribution of books per member, with the zonal library having the largest number of members $(7,500)$ but only 10 books per head. The investigator believed that the ratio of library members to total population was unacceptably low. ${ }^{9}$

In 1994-95, Ramakrishna Gowda conducted a survey of the Karnataka public library system in Chikinagalur District, a mostly rural area in the western part of Karnataka. ${ }^{10}$ The author identified thirty-two major areas of information needs and conducted 691 interviews including 421 with actual users of the libraries and 270 with potential users, in both rural and urban environments. He found that the three major needs among urban respondents were education, health, and legal information, while among rural respondents (not surprisingly) agriculture joined these fields at the top of the list. The study took note of alternative information venues including weekly bazaars (shandi), village gossip centers, and voluntary organizations (youth, women's, Rotary and Lions Clubs). One of the most striking findings of this work was that rural, and to a certain extent urban, non-users of the library system were less likely to concentrate on specific channels for relevant informa- tion, but decentralized their information-gathering sources among experienced people, friends and neighbors, government officials and experts. Both urban and rural users of the library system, on the other hand, were more likely to concentrate on newspapers, followed by friends and neighbors and then television as primary sources. Access to public libraries correlated with a greater tendency among users to focus on specific, structured information sources than among their non-participating neighbors. When asked why they visited their libraries, both urban and rural respondents identified recreation, and then current affairs, as their information goals. The presence in Chikinagalur of a delivery system weighted with Kannada fiction and periodical literature ${ }^{11}$ resulted in a user population that altered its information-gathering strategies to accord with the holdings and services of the libraries. Less than 2 percent of respondents thought the system was very helpful or that the collections were very good, and in rural areas 55 percent of users felt that the collections were bad, 40 percent feeling that the library resources were not helpful. Because most libraries were 'single-persons' institutions (which meant that if someone went on leave, the buildings closed) and the training of staff was rudimentary, only 42 percent of users indicated that library personnel were good. The author's analysis of the findings suggested that, aside from education and light reading, the libraries had not responded to expressed needs of their client population, and that a total absence of audio-visual technology was causing them to miss opportunities to address 'core socio-cultural activities' common to all surveyed groups. ${ }^{12}$

\section{A SURVEY OF PUBLIC LIBRARY USE IN BANGALORE}

The present authors coordinated a team that conducted the first user survey of the public library system in Bangalore in February 1995. In order to capture data from all parts of the city, the investigators selected the zonal libraries in each of the five zones of the city - north, south, east, west and central - where collections were fairly extensive and there were larger user populations. (In the east zone the site chosen was a branch library,

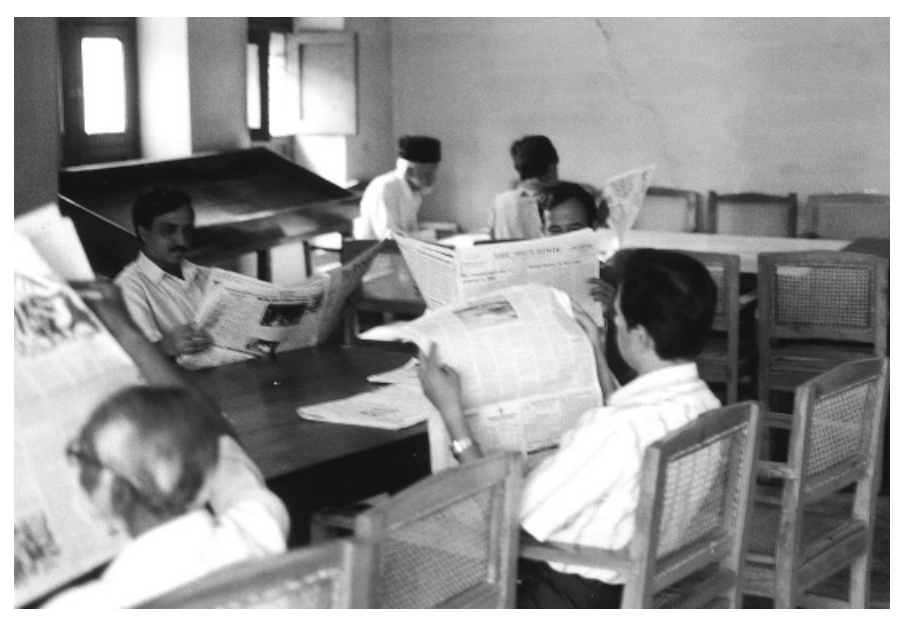

Periodicals reading room in the Haines Road Library, east zone, Bangalore. 
EVALUATION OF PUBLIC LIBRARIES IN INDIA

\begin{tabular}{|l|c|c|c|c|c|c|}
\hline Language & North & East & West & South & Center & Totals \\
\hline English & 174 & 140 & 143 & 153 & 123 & 733 \\
\hline Kannada & 120 & 94 & 170 & 141 & 136 & 661 \\
\hline Hindi & 17 & 21 & 10 & 5 & 8 & 61 \\
\hline Tamil & 10 & 17 & 5 & 7 & 9 & 48 \\
\hline Telugu & 17 & 16 & 13 & 11 & 16 & 73 \\
\hline Malayalam & 2 & 4 & 0 & 1 & 6 & 13 \\
\hline Marathi & 5 & 0 & 2 & 0 & 1 & 8 \\
\hline TOTALS & 311 & 255 & 323 & 299 & 267 & 1455 \\
\hline
\end{tabular}

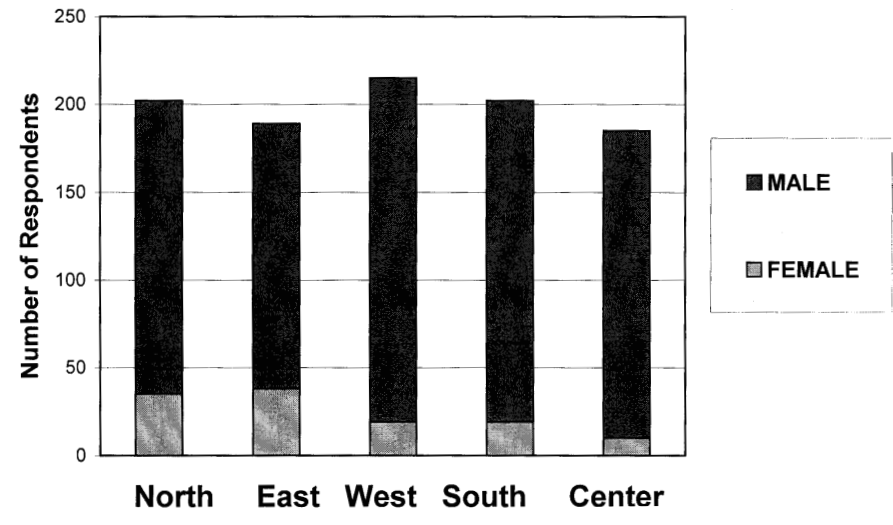

Table 2. Reading language of public library users.

which was almost as large as the zonal library and experienced more intensive use, while catering to a primarily Tamil- and Urdu-speaking clientele). ${ }^{13}$ The survey instrument was a written questionnaire, on two sides of a single sheet of paper, presenting a total of forty-two questions falling into the following categories:

1. Personal information on the respondents, including gender, age, occupation, monthly family income, marital status, and education level

2. The purpose and frequency of visits to the library

3. Opinions on the library collections and services, including

3.1. the language of books normally accessed

3.2. areas where the collection was inadequate

3.3. areas where services required improvement

3.4. options for the future of the library

3.5. quality of the library staff

For questionnaire categories 1, 2, and 3.1-3.3, users responded by choosing yes/no or by choosing one or more selections from a choice of five possible responses. For categories 3.4 and 3.5, users circled a single number between 1 and 5 to indicate the extent to which they agreed or disagreed with statements on the future or the library or the competence of its staff. Users tended to add their own commentaries or prose responses to their questionnaires, providing a wide range of linguistic data as well.

Ample copies of the questionnaire were available in either Kannada or English in the five zonal libraries, and respondents were encouraged to choose freely between the two languages. Within the 1042 questionnaires completed by respondents, there was an almost even split between Kannada and English throughout the city, but there were also obvious preferences by zone. In the north and the east, where there were larger concentrations of Tamil, Telugu, and Urdu speakers, English was the preferred language; in the south and center, where larger concentrations of Kannada speakers lived, respondents preferred the state language. A large number of the readers were competent in both English and Kannada, but English emerged as the most important reading language overall (Table 2). In fact, on a number of Kannada forms, the respondents indicated English as the reading language, normal in an environment where English remained an important language in educational institutions and employment. Telugu emerged as the third most

\begin{tabular}{|l|c|c|c|c|c|c|}
\hline Age & North & East & West & South & Center & Totals \\
\hline Below 15 years & 4 & 1 & 19 & 1 & 2 & 27 \\
\hline $15-25$ & 115 & 122 & 115 & 122 & 105 & 579 \\
\hline $26-35$ & 58 & 42 & 54 & 57 & 60 & 271 \\
\hline $36-50$ & 14 & 26 & 28 & 15 & 16 & 99 \\
\hline $51-60$ & 6 & 5 & 8 & 4 & 4 & 26 \\
\hline 61 and above & 7 & 2 & 7 & 9 & 6 & 31 \\
\hline TOTALS & 204 & 198 & 231 & 208 & 192 & 1033 \\
\hline
\end{tabular}

Table 3. Respondents by age.

important reading language, followed by Hindi (or Urdu) and then Tamil. There was a concentration of these alternative languages in the north and east zones, conforming to the linguistic geography of the city.

\section{Gender Profile of Library Users}

In the socio-economic data, there was a striking imbalance in the gender profile of the users accessed by the survey, with only 121 out of 1042 total respondents (12 percent) identifying themselves as female (Figure 1). This confirmed the visual impression of a predominantly male client base. The pattern existed in all five buildings, although in the east there were more females and the center was decidedly most skewed toward males. Data on the age of users (Table 3 ) showed equally striking concentrations within a few categories. The absolute majority of users, 579 out of 1033 respondents (56 percent), were between the ages of 15 and 25 years. If we include users aged up to 35 years, then 62 percent of users fell within the category of young adults. Children, middle-aged persons, and older persons were thus poorly represented in the user population. These findings again conformed to visual impressions that predominantly young men were present in the buildings at all times.

\section{Occupation and Income}

An indication of the commitment of respondents to the survey was the number of users who were willing to provide in- 


\begin{tabular}{|l|c|c|c|c|c|c|}
\hline Occupation & North & East & West & South & Center & Totals \\
\hline Business & 12 & 8 & 7 & 9 & 14 & 50 \\
\hline Teaching & 1 & 8 & 5 & 6 & 4 & 24 \\
\hline $\begin{array}{l}\text { Government } \\
\text { service }\end{array}$ & 14 & 19 & 16 & 10 & 9 & 68 \\
\hline Professional & 17 & 24 & 17 & 20 & 21 & 99 \\
\hline Industry & 14 & 14 & 13 & 13 & 19 & 73 \\
\hline Self-employed & 17 & 14 & 19 & 19 & 21 & 431 \\
\hline Student & 91 & 77 & 83 & 97 & 65 & 413 \\
\hline Housewife & 61 & 7 & 3 & 2 & 3 & 76 \\
\hline Unemployed & 13 & 8 & 23 & 14 & 21 & 79 \\
\hline Other & 9 & 11 & 10 & 8 & 10 & 48 \\
\hline TOTALS & 249 & 190 & 196 & 198 & 187 & 1020 \\
\hline
\end{tabular}

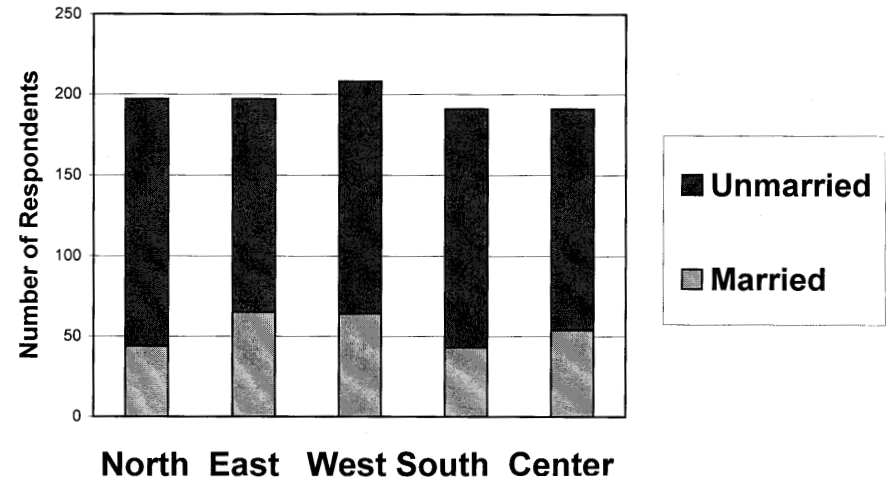

Table 4. Respondents by occupation.

\begin{tabular}{|l|c|c|c|c|c|l|}
\hline Income & North & East & West & South & Center & Totals \\
\hline $\begin{array}{l}\text { Less than } \\
\text { Rs. 1000 }\end{array}$ & 20 & 28 & 22 & 7 & 25 & 102 \\
\hline Rs. 1000-2000 & 38 & 48 & 46 & 54 & 50 & 236 \\
\hline Rs. 2001-3000 & 38 & 30 & 32 & 37 & 39 & 176 \\
\hline Rs. 3001-4000 & 22 & 20 & 20 & 23 & 19 & 104 \\
\hline Rs. 4001-5000 & 21 & 20 & 13 & 15 & 14 & 83 \\
\hline $\begin{array}{l}\text { Rs. 5001 and } \\
\text { above }\end{array}$ & 25 & 28 & 29 & 15 & 15 & 112 \\
\hline TOTALS & 164 & 174 & 162 & 151 & 162 & 813 \\
\hline
\end{tabular}

Table 5. Respondents by monthly income.

formation on their occupational background (Table 4) and their monthly household income (Table 5). Forty percent of users identified themselves as students, far larger than any other occupational category. ${ }^{14}$ The next highest response was professional occupations (10 percent); it is tempting to see in this category a large user population of lawyers, doctors or engineers, but it is more likely that users from a range of skilled trades or office environments identified themselves as professionals. Out of 121 respondents identifying themselves as female, 76 (63 percent, or 8 percent of total respondents) were housewives. ${ }^{15} \mathrm{~A}$ combination of business and self-employed persons, which we may term the 'private sector', totals 140 or 14 percent of respondents. Teaching and government service together, the 'public sector', amount to 92 or nine percent. The 'other' category, according to a number of text comments on the questionnaires, was primarily retired persons, and its low number corresponds with the small percentage of persons over 50 years old in the user population. The monthly household income of the users displays a concentration between INR 1000

Figure 2. Respondents by marital status.

(USD 32 in 1995) and INR 3000 (USD 96), accounting for 51 percent of respondents. Only 112, or 14 percent of respondents, claimed income over INR 5000 (USD 156) per month, while only 102, or 13 percent, claimed income less than INR 1000 per month. The responses were similar throughout the city. These data allow us to create a rough economic profile of the user populations in these five libraries. The majority of users come from working class or lower middle class families, with an admixture of some retired persons on pensions and some managers or professionals with higher incomes. Extremely poor people did not constitute a large percentage of patrons at the zonal libraries.

\section{Marital Status}

Information on the marital status of the users (Figure 2) reveals a very large percentage of respondents (72 percent) claiming to be unmarried. This conforms to the age and occupational profiles discussed above, refining the picture of the average user as an unmarried, male student. In keeping with this picture, it is not surprising that only 174 respondents claimed that they had any children, and even among that group, the number of children was typically two or less (Table 6). This means that either a number of young married people had not had time to build larger families, or were deliberately keeping the number of children low. ${ }^{16}$

\begin{tabular}{|l|c|l|l|l|l|c|}
\hline Children & North & East & West & South & Center & Totals \\
\hline One & 14 & 11 & 15 & 13 & 17 & 70 \\
\hline Two & 5 & 17 & 11 & 10 & 12 & 55 \\
\hline Three & 5 & 11 & 5 & 2 & 6 & 29 \\
\hline Four & & 14 & & 1 & & 15 \\
\hline More than four & & 3 & 1 & 1 & & 5 \\
\hline TOTALS & 24 & 56 & 32 & 27 & 35 & 174 \\
\hline
\end{tabular}

Table 6. Respondents by number of children.

\section{Educational Profile}

The educational profile of respondents (Table 7) displays a concentration (34 percent) of college graduates, many of whom 


\begin{tabular}{|l|c|c|c|c|c|c|}
\hline $\begin{array}{l}\text { Education } \\
\text { level }\end{array}$ & North & East & West & South & Center & Totals \\
\hline Below SSLC & 2 & 13 & 4 & 3 & 10 & 32 \\
\hline SSLC & 20 & 39 & 49 & 25 & 49 & 182 \\
\hline Diploma & 26 & 31 & 25 & 21 & 28 & 131 \\
\hline Graduate & 78 & 66 & 74 & 67 & 53 & 338 \\
\hline Post-graduate & 22 & 13 & 15 & 21 & 7 & 78 \\
\hline $\begin{array}{l}\text { Professional } \\
\text { degree }\end{array}$ & 48 & 29 & 42 & 61 & 39 & 219 \\
\hline TOTALS & 196 & 191 & 209 & 198 & 186 & 980 \\
\hline
\end{tabular}

Table 7. Education level of respondents.

must have been continuing as students along with holders of SSLC (Secondary School Leaving Certificate) and diploma. There was a very low presence (3 percent) of persons below the SSLC level, coinciding with the poor representation of children and also persons with very low income who might presumably have low education. The reason for the large percentage of persons with professional degrees (22 percent) may lie in a tendency to inflate professional qualifications or to equate training in a variety of technical areas with professionalism. It indicates, however, along with the high incidence of graduates, the presence of a relatively well-educated clientele in these libraries. Their personal educational qualifications did not correspond with high incomes or distinguished employment, and many of these users were in the process of upgrading their skill levels, apparently in the pursuit of career upgrades.

\section{Patterns of Library Use}

A remarkably large number of the respondents (39 percent) claimed that they visited the library every day, while an additional 29 percent claimed that they visited the library at least every week (Table 8). This indicates that a number of regular patrons, for whom the institution was an important feature in their lives, regularly filled the libraries. The more 'traditional' pattern of library use, with patrons dropping in at regular or irregular intervals to engage the book collection, differs from the dominant pattern observed in the Bangalore zonal libraries.

\begin{tabular}{|l|c|c|c|c|c|c|}
\hline Frequency & North & East & West & South & Center & Totals \\
\hline Every day & 92 & 41 & 85 & 84 & 92 & 394 \\
\hline Weekly & 59 & 83 & 60 & 44 & 44 & 290 \\
\hline Fortnightly & 6 & 48 & 13 & 16 & 5 & 88 \\
\hline Monthly & 2 & 4 & 1 & 6 & 5 & 18 \\
\hline Occasionally & 39 & 21 & 58 & 58 & 50 & 226 \\
\hline TOTALS & 198 & 197 & 217 & 208 & 196 & 1016 \\
\hline
\end{tabular}

Table 8. Frequency of visits to the library.

\begin{tabular}{|l|c|c|c|c|c|c|}
\hline Purpose & North & East & West & South & Center & Totals \\
\hline Book borrowing & 2 & 13 & 4 & 3 & 10 & 32 \\
\hline To return a book & 20 & 39 & 49 & 25 & 49 & 182 \\
\hline $\begin{array}{l}\text { To read } \\
\text { newspapers }\end{array}$ & 26 & 31 & 25 & 21 & 28 & 131 \\
\hline To read magazines & 78 & 66 & 74 & 67 & 53 & 338 \\
\hline Any other work & 22 & 13 & 15 & 21 & 7 & 78 \\
\hline $\begin{array}{l}\text { Preparation for } \\
\text { competitive exams }\end{array}$ & 48 & 29 & 42 & 61 & 39 & 219 \\
\hline TOTALS & 196 & 191 & 209 & 198 & 186 & 980 \\
\hline
\end{tabular}

Note: The response 'Preparation for competitive exams' existed only on Kannada forms.

Table 9. Reasons for users' visits to the public library.

Users indicated that on the day they filled out the questionnaire only 24 percent of them had come for book borrowing or book returning, while 60 percent had come to read newspapers and magazines (Table 9). Preparation for competitive examinations offered by the state government motivated 8 percent of these visitors. If users were interested in research and reference, they may appear in the category of 'other work' which accounts for only 8 percent of the visitors. The prose responses from this part of the questionnaire support the findings that periodical literature was the main goal for most readers. There were only fifty-two statements (two in Kannada) indicating that books were the target, but ninety-two statements (forty in Kannada) indicating that newspapers and magazines were the target. When asked what physical section of the library they ordinarily used, 35 percent of the respondents indicated (Table 10) that the section for reading periodicals was the most important, followed by the sections for novels (21 percent), textbooks (16 percent), and competitive examinations (13 percent). ${ }^{17}$ In addition, among a total of 332 prose responses that provided explicit statements on the types of literature users were accessing,

\begin{tabular}{|l|c|c|c|c|c|l|}
\hline Section & North & East & West & South & Center & Totals \\
\hline Newspapers & 42 & 39 & 60 & 69 & 89 & 299 \\
\hline Text books & 35 & 20 & 17 & 45 & 22 & 139 \\
\hline Novels & 20 & 86 & 30 & 24 & 21 & 181 \\
\hline Children's section & 8 & 6 & 4 & 7 & 2 & 27 \\
\hline Reading section & 20 & 8 & 8 & 33 & 7 & 76 \\
\hline $\begin{array}{l}\text { Book section for } \\
\text { competitive exams }\end{array}$ & 29 & 8 & 23 & 38 & 17 & 115 \\
\hline Other & 2 & 6 & 3 & 8 & 6 & 25 \\
\hline TOTALS & 156 & 173 & 145 & 224 & 164 & 862 \\
\hline
\end{tabular}

Note: This question appeared only on Kannada questionnaires.

Table 10. Sections of public libraries frequented by users. 


\begin{tabular}{|l|rl|}
\hline Newspapers and magazines & $92 \quad(4)^{*}$ \\
\hline Literature (including novels) & $52 \quad(2)$ \\
\hline Study/textbooks & 44 \\
\hline Reference & 25 \\
\hline Business/economics & $19 \quad(2)$ \\
\hline Books & $13 \quad(1)$ \\
\hline Computers/electronics & $12 \quad(5)$ \\
\hline Science/technology & $10 \quad(1)$ \\
\hline Engineering & $10 \quad(1)$ \\
\hline Medicine/pharmacology & 7 & $(2)$ \\
\hline Politics & 7 & $(1)$ \\
\hline History & 6 & $(1)$ \\
\hline Mathematics & 5 & $(2)$ \\
\hline Philosophy/religion & 5 & $(1)$ \\
\hline Education & 4 \\
\hline Chemistry & 3 & $(1)$ \\
\hline Law & 3 & $(1)$ \\
\hline Writing & 3 \\
\hline Sports & 3 \\
\hline Biology & 2 \\
\hline Psychology & 2 \\
\hline Art & 1 \\
\hline Leisure & 1 \\
\hline Photography & \\
\hline
\end{tabular}

*Numbers in parentheses indicate Kannada responses.

Table 11. Literature accessed by users of Bangalore public libraries.

newspapers and magazines again topped the list, followed by literature such as novels (Table 11). These statements showed a marked preference for business, technical and scientific writings that could enhance career prospects.

Among the prose statements, one writer described his activities as 'reference study', and another claimed to be 'referring subject books'. Perhaps the most illuminating glimpse into the motivations of the predominantly student population was this: 'My intention of coming to the library for reference purpose and research and prepare and don't have anything in my mind'. Some of the students were bringing their school text books to the library and performing their studies in a neutral or fairly quiet environment. The respondents regularly combined notions of research, reference, study, and preparation for examinations, since indeed they were typically in the process of performing all of these activities in order to 'study for change'. Some users indicated that they came primarily for popular lit-

erature, and one respondent honestly revealed that he was looking for 'novels that are prescribed for my income'. Many responses, however, showed that access to literature - primarily novels and other fiction - was a priority only alongside access to other kinds of resources, including periodicals. In addition, many users were utilizing the periodicals to perform research, particularly in job searches or in skill enhancement. It seems clear, in the final analysis, that reading for most of the users of the public libraries meant reading of periodical literature, and that the book collections, while important, were a secondary goal or perhaps not a goal for a large percentage of library patrons. Neither the clientele interested in the literature holdings, nor the clientele interested in research or reference books or study guides, were a plurality of the daily visitors.

\section{Opinions on Library Collections}

We examine now the user responses to the collections. When asked directly about their opinion of the library collections, users' opinions were rather negative, with 64 percent of respondents rating the collections as either old or obsolete (Figure 3).

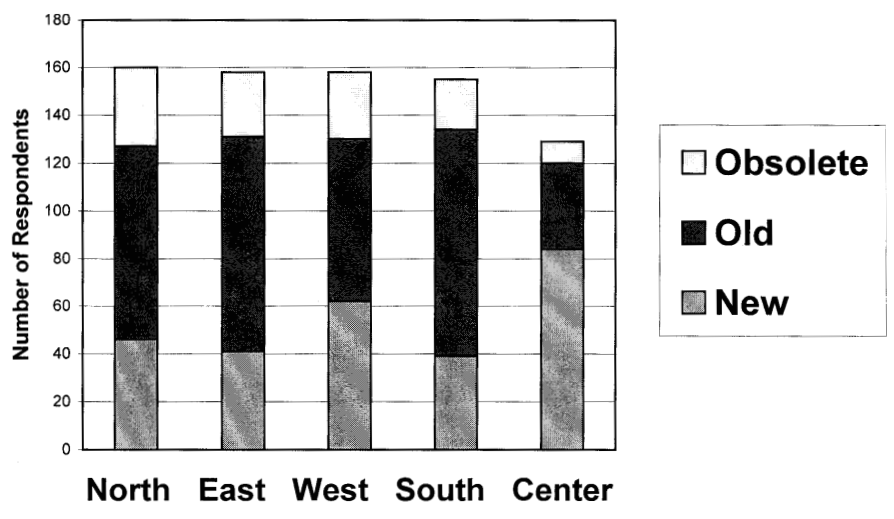

Figure 3. Respondents' opinion of public library collections.

It is possible that even those rating the collection as new were referring to periodical literature rather than the book collection. A number of completed forms included responses for new and old together, suggesting that for some users there was a division between new periodicals and some new books on one hand, and an older collection on the other. The library in the central zone, which was a new building with presumably newer books, displayed a marked reversal of the pattern, with most users rating the collection as new. This response indicates that the branches were financially incapable of updating materials, including encyclopedias or other reference sources, once they were on the shelves. When asked if they thought the collections were appropriate, however, the majority of users (68 percent) answered affirmatively (Table 12). This may mean that most users coming to read periodicals were content with the newspapers and magazines available on a daily basis. Dissatisfied users amounted to 32 percent, who may represent the body of patrons who accessed the reference and book collections. Corroboration for these hypotheses comes from user suggestions on the type of collection needing strengthening. 
Is the library collection appropriate to your needs or choice?

\begin{tabular}{|l|c|c|c|c|c|l|}
\hline & North & East & West & South & Center & Totals \\
\hline Yes & 68 & 90 & 69 & 76 & 80 & 383 \\
\hline No & 37 & 33 & 36 & 49 & 27 & 182 \\
\hline TOTALS & 105 & 123 & 105 & 125 & 107 & 565 \\
\hline
\end{tabular}

If no, what type of collection needs to be strengthened?

\begin{tabular}{|l|c|c|c|c|c|c|}
\hline Collection & North & East & West & South & Center & Totals \\
\hline Books & 28 & 66 & 36 & 35 & 24 & 189 \\
\hline Magazines & 34 & 24 & 37 & 25 & 25 & 145 \\
\hline Newspapers & 27 & 5 & 47 & 35 & 43 & 157 \\
\hline Reference books & 52 & 52 & 41 & 42 & 26 & 213 \\
\hline Text books & 65 & 43 & 45 & 57 & 43 & 253 \\
\hline $\begin{array}{l}\text { Books on } \\
\text { competitive exams }\end{array}$ & 37 & 28 & 36 & 42 & 18 & 161 \\
\hline TOTALS & 243 & 218 & 242 & 236 & 179 & 1118 \\
\hline
\end{tabular}

Table 12. Appropriateness of library collections to users.

Fifty-six percent of respondents indicated that the reference collection as a whole, including text books and books on competitive examinations, required improvement. This is a very high rate of response when compared to the percentage of users who stated that they used these resources (Table 9); the reason that more patrons did not use them perhaps lay in the poor public opinion of their quality. Newspapers and magazines, which typically attracted most patrons, still accounted for 27 percent of responses indicating need for improvement, which indicates that some upgrading even here was necessary. Interestingly, the book collection required improvement for only 17 percent of respondents, which suggests either that it was already adequate for most users or that much of the user population did not care about it. However, among the 105 prose responses to this section of the questionnaire that directly indicated what areas needed improvement, fifty-nine (56 percent) advocated an increase in the book collection. Sixteen commentators (15 percent) wanted additional text books, twenty-seven ( 25 percent) wanted better newspaper holdings, and only seven advocated changes in the reference collection. These comments suggest again that the book collection (including textbooks) was inadequate for a substantial proportion of the user population. It seems likely that the users who wanted to access books were particularly unhappy with the selections and were willing to express their frustration, while those who did not access books were either disenchanted with the collections from the beginning or always had a primary interest in periodical literature.

Table 13 presents overall responses to library services. According to text comments, users interpreted the query to mean the services provided by the library staff, so for many people this query elicited a personnel evaluation in contrast to collec-
Is the library service compatible to your needs?

\begin{tabular}{|l|c|c|c|c|c|l|}
\hline & North & East & West & South & Center & Totals \\
\hline Yes & 103 & 117 & 90 & 101 & 97 & 508 \\
\hline No & 19 & 21 & 28 & 39 & 12 & 119 \\
\hline TOTALS & 122 & 138 & 118 & 140 & 109 & 627 \\
\hline
\end{tabular}

If no, what is lacking?

\begin{tabular}{|l|c|c|c|c|c|c|}
\hline & North & East & West & South & Center & Totals \\
\hline Collection & 53 & 57 & 53 & 50 & 30 & 243 \\
\hline Approach & 11 & 14 & 15 & 16 & 10 & 66 \\
\hline Timeliness & 13 & 16 & 25 & 16 & 27 & 97 \\
\hline $\begin{array}{l}\text { Public relations/ } \\
\text { communications }\end{array}$ & 21 & 21 & 28 & 19 & 24 & 113 \\
\hline TOTALS & 98 & 108 & 121 & 101 & 91 & 519 \\
\hline
\end{tabular}

Table 13. Compatibility of library service to users' needs.

tion evaluation (Table 12). There was good news here, since 81 percent of respondents thought the services of the libraries, or at least their staffs, to be adequate. This left a substantial minority of users who found services inadequate. The reason for inadequacy, however, was again the collection for 48 percent of users, although public relations and timeliness - issues addressed at the human resource level - were major concerns as well for 40 percent of respondents. The overall approach of the libraries was not a negative feature for many users.

\section{Recommendations for Change}

Users made clear recommendations for changes in the libraries, summarized in Table 14. Topping the list of recommendations, not surprisingly, was availability of documents, with 31 percent of responses calling for additional investment in the collection. Out of 298 appended prose comments, 120 described the areas of the holdings that needed upgrade: forty-two advo-

\begin{tabular}{|l|c|c|c|c|c|c|}
\hline Changes & North & East & West & South & Center & Totals \\
\hline Opening hours & 36 & 27 & 51 & 38 & 62 & 214 \\
\hline $\begin{array}{l}\text { Timeliness of } \\
\text { service }\end{array}$ & 41 & 20 & 42 & 40 & 20 & 163 \\
\hline Staff assistance & 42 & 35 & 46 & 41 & 25 & 189 \\
\hline Lending system & 41 & 35 & 33 & 27 & 25 & 161 \\
\hline $\begin{array}{l}\text { Availability of } \\
\text { documents }\end{array}$ & 96 & 67 & 64 & 86 & 55 & 368 \\
\hline Staff behavior & 22 & 10 & 28 & 31 & 11 & 102 \\
\hline TOTALS & 278 & 194 & 264 & 263 & 198 & 1197 \\
\hline
\end{tabular}

Table 14. Changes in library services suggested by users. 
cated more books (split between fiction and the sciences), thirty-two wanted better periodicals, twenty-five more textbooks, and twenty-one urged better reference sections. The second most important change was opening hours, mentioned by 18 percent of the statistical responses and by twenty-five ( 8 percent) of the prose comments as well. These users wanted the libraries to eliminate Monday as a day off and to open earlier in the day, so that they might read the newspapers before heading to work. One comment expressed the needs of the large proportion of student users: 'Change is required because poor students have no facility to read at home. Library should be kept open for 24 hours.' Next in importance was staff assistance, which stood in contrast to opinions on staff behavior (see below). According to many comments, the library staff received high marks as people and professionals (One user wrote, 'The library staff are like god' but there were problems in their ability to help users. Part of the difficulty was the absence of a catalogue system, mentioned in seventeen prose comments as a needed improvement. We should note that eighty-eight prose comments (31 percent) explicitly stated that the library system was either good, satisfactory or not bad.

\section{Opinions of Facilities and Staff}

The final category of responses captured by the questionnaires included twenty questions eliciting user opinions on facilities and staff service, on a scale from one (strongly agree) to five (strongly disagree). Many respondents treated these as yes/no questions, choosing either one or five, thus creating bi-modal data sets. Users left many questions blank, but responded most often to 1 ('Maintain present status'), 7 ('Strengthen the collection') and 8 ('Staff are helpful'). The responses indicated that users were generally disposed to keep the current situation, with the strongest scores from the newest building in the central zone. Strengthening the collection received the highest priority in all libraries, with low standard deviations. Staff also received very high marks, and one user wrote, 'Present staff members are really good! Especially the librarians.' In more practical questions on facilities improvement, respondents viewed computerization as the most important change. Questions with negative connotations for staff received decidedly negative responses, providing support for the staff as people and as professionals. On the other hand, question 19 ('They need better training') received considerable support. These findings in combination with those from Table 13 suggest areas where improvement of staff performance was possible. One user had a final piece of advice: 'very one from the library should be courteous and the library should strive for the upliftment of Kannada'.

\section{ANALYSIS OF SURVEY RESULTS}

The data presented here indicate that, although a substantial minority was greatly dissatisfied, most users of the Bangalore public libraries were satisfied with the general direction of the five zonal facilities. The data suggest some areas within all libraries and, in some cases, within particular buildings, where improvement of the current systems was possible in relation to quantifiable goals (e.g. response time to certain types of infor- mation needs), basic infrastructure (continuous power supply and toilet facilities), and overall supervision of the buildings. ${ }^{18}$ The survey revealed, however, important problems connected to the user population and to the quality of services that required policy decisions.

Most of the users of the zonal libraries were young men who came to the buildings in an attempt to get out of their houses and read free newspapers and magazines that they could not afford to purchase personally. ${ }^{19}$ The public library system was performing a valuable service for this population, who were relatively well educated but who were unemployed or underemployed and used the library to aid their transition to loweror mid-level careers. It is clear, however, that the library system as originally envisaged was not targeted to this population to such an extent. Other target populations - women, the elderly, and children - were under-represented. To some extent, the very success of the libraries in attracting young men, combined with the spatial organization of the buildings, contributed to limitations on women's presence. During much of the day, the male readers monopolized the majority of seats in the buildings, creating a formidable mass that could put off potential female patrons or children. This left women with space in and around the stacks, where they could browse for (mostly fictional) literature, chat at the circulation desk, and then head out the door, mostly in the evenings. The cultural patterning of space and time contributed to a highly gendered environment mirrored in the survey statistics. Paradoxically, the gendering of the libraries may have limited the very populations who could be interested in the more extensive collections of literature (including Kannada novels) that ate up a considerable percentage of the budget. Thus, one of the main issues facing the library system was not attracting more clients, but diversifying the client base.

The survey indicated a consensus among users that the library collections needed improvement. One general comment in English, a backhanded compliment, perhaps summarizes user reactions to the collection: 'Very good material to study available sometimes'. Another response in English encapsulated the critiques of the holdings:

Mostly required:

1) educational-technical -reference books

2) books to enlighten career \& professional paths

3) proper maintenance, easy availability

4) strict vigilance to secure good, costly books

5) English contemporary novels

6) Kannada top.

Students who made use of preparatory materials for competitive examinations or for self-improvement in technical fields seemed particularly unhappy with the resources available in the libraries. One respondent in English suggested, 'There are not so many books on electronics. Though we find a few, they are not for reference, so please arrange for these books so that we can refer it at home leisurely.' This raises the question of whether the public library system should have shouldered more responsibility for supporting examinations monitored or regulated by the government, or for investing limited funds in technical literature to support the educational system or post-degree 
Questionnaire sections 3.5 and 3.5

What are your options for the future of this library?

1. Maintain present status

2. Go with AV material

3. Go for automation (computer)

4. Changes in service

5. Card catalogue

6. Lending system

7. Strengthen the collection
What are your impressions about the library staff?

8. Helpful

9. Not courteous

10. They are knowledgeable about library work

11. They lack skills to serve

12. They approach any problems analytically

13. They could not understand my problem

14. They have no solution to our problems

15. They take optimum time to serve

16. Delay is deliberate

17. Problems in higher levels

18. Lower level staff helpful

19. They need better training

20. The qualifications they possess are inadequate

Responses to questionnaire sections 3.5 and 3.6

\begin{tabular}{|c|c|c|c|c|c|c|c|c|c|c|c|c|c|c|c|c|c|c|}
\hline \multirow[b]{2}{*}{ Response } & \multicolumn{3}{|c|}{ North } & \multicolumn{3}{|l|}{ East } & \multicolumn{3}{|c|}{ West } & \multicolumn{3}{|c|}{ South } & \multicolumn{3}{|c|}{ Center } & \multicolumn{3}{|c|}{ All libraries } \\
\hline & No. & Mean & S.D. & No. & Mean & S.D. & No. & Mean & S.D. & No. & Mean & S.D. & No. & Mean & S.D. & No. & Mean & S.D. \\
\hline 1 & 122 & 2.10 & 1.58 & 133 & 2.59 & 1.65 & 125 & 2.34 & 1.67 & 129 & 2.51 & 1.67 & 117 & 1.70 & 1.29 & 626 & 2.26 & 1.61 \\
\hline 2 & 94 & 2.39 & 1.59 & 86 & 2.51 & 1.57 & 95 & 2.57 & 1.65 & 101 & 2.54 & 1.62 & 85 & 2.13 & 1.49 & 461 & 2.44 & 1.59 \\
\hline 3 & 122 & 1.89 & 1.46 & 104 & 2.01 & 1.50 & 101 & 2.23 & 1.57 & 125 & 1.86 & 1.48 & 94 & 2.03 & 1.58 & 546 & 1.99 & 1.52 \\
\hline 4 & 112 & 2.71 & 1.69 & 96 & 2.79 & 1.57 & 108 & 2.35 & 1.58 & 118 & 2.40 & 1.60 & 77 & 3.05 & 1.67 & 511 & 2.63 & 1.64 \\
\hline 5 & 110 & 2.14 & 1.49 & 84 & 1.99 & 1.61 & 99 & 2.14 & 1.49 & 102 & 2.21 & 1.60 & 68 & 2.07 & 1.47 & 463 & 2.12 & 1.54 \\
\hline 6 & 68 & 2.13 & 1.44 & 86 & 2.20 & 1.47 & 73 & 2.15 & 1.47 & 61 & 2.23 & 1.55 & 50 & 1.94 & 1.33 & 338 & 2.14 & 1.46 \\
\hline 7 & 153 & 1.65 & 1.39 & 132 & 1.67 & 1.33 & 141 & 1.67 & 1.34 & 125 & 1.57 & 1.29 & 106 & 1.70 & 1.40 & 657 & 1.65 & 1.35 \\
\hline 8 & 160 & 1.48 & 0.96 & 156 & 1.66 & 1.15 & 164 & 1.89 & 1.44 & 152 & 1.93 & 1.46 & 149 & 1.50 & 1.12 & 781 & 1.70 & 1.26 \\
\hline 9 & 71 & 2.63 & 1.48 & 90 & 3.42 & 1.63 & 104 & 3.38 & 1.67 & 108 & 3.20 & 1.66 & 83 & 3.47 & 1.75 & 456 & 3.25 & 1.67 \\
\hline 10 & 120 & 1.97 & 1.29 & 117 & 2.55 & 1.61 & 112 & 2.26 & 1.47 & 111 & 2.75 & 1.65 & 112 & 1.86 & 1.33 & 572 & 2.27 & 1.51 \\
\hline 11 & 89 & 2.60 & 1.55 & 101 & 3.01 & 1.67 & 98 & 3.43 & 1.57 & 103 & 3.12 & 1.66 & 83 & 3.35 & 1.72 & 474 & 3.10 & 1.66 \\
\hline 12 & 110 & 2.28 & 1.48 & 100 & 3.08 & 1.65 & 111 & 2.76 & 1.65 & 101 & 2.94 & 1.72 & 94 & 2.38 & 1.64 & 516 & 2.59 & 1.65 \\
\hline 13 & 108 & 3.49 & 1.66 & 96 & 3.46 & 1.54 & 105 & 3.30 & 1.67 & 99 & 3.26 & 1.70 & 89 & 3.97 & 1.52 & 497 & 3.48 & 1.64 \\
\hline 14 & 106 & 3.56 & 1.63 & 91 & 3.25 & 1.49 & 99 & 3.11 & 1.68 & 103 & 2.97 & 1.80 & 79 & 3.61 & 1.69 & 478 & 3.29 & 1.68 \\
\hline 15 & 114 & 2.32 & 1.60 & 105 & 2.51 & 1.57 & 107 & 2.48 & 1.58 & 102 & 2.77 & 1.63 & 103 & 2.07 & 1.48 & 531 & 2.43 & 1.59 \\
\hline 16 & 97 & 3.42 & 1.63 & 91 & 3.92 & 1.41 & 98 & 3.44 & 1.65 & 102 & 3.02 & 1.77 & 72 & 3.78 & 1.62 & 460 & 3.49 & 1.65 \\
\hline 17 & 105 & 2.90 & 1.69 & 86 & 3.41 & 1.65 & 98 & 3.03 & 1.62 & 95 & 3.13 & 1.69 & 72 & 3.29 & 1.76 & 456 & 3.13 & 1.69 \\
\hline 18 & 107 & 2.04 & 1.37 & 93 & 2.65 & 1.66 & 95 & 2.46 & 1.53 & 100 & 2.54 & 1.66 & 75 & 2.33 & 1.66 & 470 & 2.40 & 1.58 \\
\hline 19 & 120 & 2.23 & 1.60 & 100 & 2.31 & 1.64 & 111 & 2.19 & 1.58 & 112 & 2.00 & 1.51 & 88 & 2.88 & 1.78 & 531 & 2.30 & 1.64 \\
\hline 20 & 106 & 2.95 & 1.67 & 93 & 3.32 & 1.65 & 95 & 3.09 & 1.65 & 106 & 2.83 & 1.70 & 75 & 3.57 & 1.64 & 475 & 3.12 & 1.69 \\
\hline
\end{tabular}

Table 15. Users' suggestions for public library improvement.

technical training. Increased budgetary allocations for examination materials would undoubtedly increase the population of users frequenting the library buildings solely for the purpose of studying these materials, which might not contribute to an increased diversity of the user population. On the other hand, if the library system did not provide this kind of sup- port, who would? A larger issue of collection development was the general weakness in research materials. Because many of the patrons had already finished their formal education and no longer had access to whatever collections existed in their schools, they depended on the public libraries to provide general reference books and basic collections in specific disciplines. 
The libraries were not doing enough to satisfy these research needs of users.

The users were generally positive about staff behavior and the desire of the library personnel to respond to their information needs, indicating that staff recruitment and morale remained nonproblematic. The big issue for both staff and users lay in budgetary allocations for training and for equipment, as suggested by one general comment in English: 'This library is functioning in an excellent manner and the authorities must encourage the staff/readers by providing necessary amenities.' A solution supported by users: computerize the catalogues of the entire system and set up an inter-library loan network.

The kinds of services offered by the public library system in Bangalore differed in scale, but not in kind, from those offered by the system in rural Chikinagalur. The holdings in both areas were print-based, primarily newspapers and Kannada literature. The response to these holdings was more negative in the countryside because these source materials, emanating primarily from urban scenes, had much less relevance for the predominantly agricultural population, while the services possible in the mostly single-person libraries were more rudimentary and intermittent. The zonal libraries in Bangalore, despite their limitations, offered more pleasant surroundings and a depth of information services that were simply not provided in rural and underprivileged neighborhoods. The public library thus embedded a hierarchy its services, with an urban bias in the quality of its limited resource deployment.

While the entertainment or recreational aspect of library services remained important, a substantial body of opinion among the clientele wanted the public library to become a component within a multi-institutional educational matrix that provided information for job training, whether it was agricultural outreach in rural areas or a variety of scientific and technology disciplines in the city. The public library system could thus more self-consciously view itself as an institutional partner with high schools, colleges, and technology training institutes. The impressive body of dedicated library users who were hungry for a broadening of the library system's mission represented, however, a relatively narrow socio-economic stratum. Although service provision even for this group was stretching budgets, materials and space to their limits, a continued concentration on serving only the current clientele isolated the libraries from women, children, and both the very poor who really needed help and the well-to-do who could help the system. It was a problem of expanding services to a more varied consumer base.

\section{THE PUBLIC LIBRARY SYSTEM'S RESPONSE}

Between 1995 and 2000, the public library system pursued a two-front strategy to improve its services. On the rural front, there was a more intensive concentration on the expansion of services to more places, especially in the poorer, northern districts of the state (the home of the department's director). In 1998-99, the system opened 500 libraries in villages where local assemblies (panchayats) had their seats. Each location received an infusion of INR 30,000 at the beginning, and an annual budget of INR 20,000 that included monthly salary of about INR 750 to support personnel who would keep the li- braries open in the evenings. The collections initially included a few books, but more important were subscriptions to newspapers. The purpose of this initiative was to encourage the activity of reading and to provide a platform that would allow rural literates to keep up their skills. For urban libraries, the main goal was computerization. In 1997, the Department made a firm commitment to mount an online catalogue at the State Central Library in Bangalore. They bought new hardware and the software TechLib (using a Foxbase+ database application) marketed by the National Informatics Centre (NIC), and engaged a private firm to oversee data entry and validation along with systems support. By the middle of 1999, the approximately 250,000 records of the library holdings were entered and available for searching on an experimental basis. For the general catalogue, there were separate indexes for English-language materials accessible through English commands, and Kannadalanguage materials accessible through Kannada commands. Separate indexes were available for materials in the copyright collection. The goal was to provide four terminals for users, with hard copy instructions on how to use the system in both languages, plus terminals for the librarian and for technical support as well as a link provided by NIC to a terminal in the departmental headquarters about one kilometer away. The next stage involved a web site as well as a union catalogue with a single zonal library in Bangalore, before moving toward a wide area network. ${ }^{20}$

In conversations following up the surveys in 1995, the director and other administrators of the public library system indicated that the main priorities remained in the rural areas. There would be little change in the official strategy of increasing the number of village sites where the most basic of services would become available, most notably, providing daily newspapers and Kannada literature. In a state where millions of villagers still earned less than USD 300 per year, and given the constraints of resources on the library system, this goal alone remained quite ambitious. The evaluations described in this article indicate, however, that a strategy of churning out bigger numbers required a concomitant sensitivity to information sophistication among targeted users. The literate clientele in rural areas was becoming more restive, looking for the technical and management information needed in a liberalizing, agrarian market economy. In urban areas, the drive toward career improvement was pushing a relatively young clientele toward up-to-date technical and professional literature. Some of these problems could be solved in part by cataloguing and inter-library loan processes, which were coming into effect very slowly. Added attention was necessary to avoid obsolescence of crucial reference holdings, which alienated a large proportion of the current clientele. The library system thus had to continually upgrade the quality of its delivery mechanisms and delivered documents within specific locales, in addition to simply increasing the volume of very basic services. The evaluations also revealed what everybody knew but nobody wanted to admit - that the public library system was spending most of its resources meeting the information needs of a relatively narrow social stratum, failing to attract the very young, the very old, and a large proportion of the female population. Augmented sensitivity to the limitations inherent in the very success of its planning 
model would be necessary in order to alter the age and gender characteristics of the user population.

\section{Notes}

1. Among the 15 major Indian states, Karnataka in the early 1990s was seventh in literacy and sixth in per capita net domestic product, sixth in life expectancy, infant mortality and maternal mortality rates. The average per capita income in Indian states was INR 6249 (USD 200); Karnataka's was in tenth place, at INR 6313. The United Nations human development index, when applied to India, yielded a figure of 0.439 , giving the nation a rank of 134 among 174 countries in the world. If applied only to the state of Karnataka, the index yielded a figure of 0.472 , only slightly above the national norm. The composite human development index (HDI), developed by the United Nations Development Program (UNDP) for its first Human Development Report in 1990, covered three indicators: longevity, educational attainment, and standard of living measured by real gross domestic product per capita (Human Development in Karnataka 1999. Bangalore: Planning Department, Government of Karnataka (1999) pp. 5-7, 13).

2. For a representative example of literature on Bangalore as Silicon Valley, see Arvind Singhal, India's Information Revolution, New Delhi and Newbury Park, CA: Sage Publications (1989); Edward Yourdon, Decline E Fall of the American Programmer, Englewood Cliffs, NJ: Yourdon Press (1992) pp. 279-312; Shirin Madon, 'Information-based global economy and socioeconomic development: the case of Bangalore', The Information Society, 13 (1997) pp. 22743; Yasmin Mahmood, 'India's silicon city', Aramco World, (November/December 1997) pp. 37-42; 'Hartetest im Paradies', [Hard test in paradise], Der Spiegel, 40 (29 September 1997) pp. 129-38; William Wolman and Anne Colamosca, The Judas Economy: The Triumph of Capital and the Betrayal of Work, Reading, MA: Addison-Wesley (1997) pp. 83-106; Bob Davis and David Wessel, Prosperity: The Coming Twenty-year Boom and What it Means to You, New York: Random House (1998) pp. 218-37; James Heitzinan, 'Corporate strategy and planning in the science city: Bangalore as "Silicon Valley",' Economic and Political Weekly 34: 5 (January 30-February 5, 1999), pp. PW2PE11; 'Technologieregion Bangalore: Neues Modell fur Innovationsorientierte Regionalentwicklung?' [Technology region Bangalore: new model for innovation-oriented regional development?], Geographische Runschau 51 (1999) pp. 96-102.

3. P. Thippaiah, 'Informal Sector and the Urban Poor in a Metropolitan Area: A Case Study of Bangalore', Ph.D. dissertation, Bangalore: University of Bangalore (1993); M.J. deWit, Geographical Information Systems, Remote Sensing and Slums in Indian Cities: The Case of Bangalore, IDPAD 1992-8, Amsterdam: Indo Dutch Programme on Alternatives in Development (1992) pp. 17-18, 43, 59-60; Bangalore Development Authority, Comprehensive Development Plan (Revised) Bangalore - Report, Bangalore: Bangalore Development Authority (1995) pp. 25-27; A.
Ravindra, B.K. Chandrashekar, V. Govindraj and P.S.S. Thomas, The Committee on Urban Management of Bangalore City: A Report Submitted to the Government of Karnataka, Bangalore: Government of Karnataka (1997) pp. 92-158; Citizens' Voluntary Initiative for the City (CIVIC Bangalore), City Profile of Bangalore, Bangalore: CIVIC Bangalore (1999).

4. Human Development in Karnataka (1999) p. 263.

5. After 1965, the Department of Public Libraries functioned as a division under the Karnataka State Ministry for Adult Education, Vocational Education, Public Libraries and Stationery. The Mysore Public Libraries Act, 1965 and The Rules and Notifications thereunder, Mysore Act No. 10 of 1965, Bangalore: Government of Mysore Department of Law and Parliamentary Affairs (1967); P.K. Patil, Public Libraries in Karnataka: Their Scope and Development, Bangalore: Department of Public Libraries, Government of Karnataka (1982); T. Malleshappa, 'Public libraries in Karnataka', In: T. Malleshappa (ed.), Indian Library Association Diamond Jubilee Celebration and XXYLY All India Library Conference, Bangalore 7-10 January, 1994, Bangalore: Department of Public Libraries, Government of Karnataka (1994) pp. 23-27; Sarvajanika granthalaya ilakbe: pragati nota [The Department of Public Libraries: A Look at Progress], Bangalore: State Central Library (1994) pp. 10, 15-24. Statistics for 1999 come from the display mounted at the offices of the Karnataka State Department of Public Libraries, and from an interview with T. Mallesappa, Director, on 16 August 1999.

6. H.A. Khan, 'Public libraries and the contemporary Indian society’, In: H.A. Khan and S.R. Ijari (ed.), Current Problems and Trends in Library and Information Services, Varanasi: Indian Bibliographic Centre (1990) pp. 166-72; 'Problems and prospects of public libraries in the four library law states in India', Ph.D. dissertation, Dharwad: Karnataka University (1985) pp. 457-67.

7. P. Sankaralingam and K.S. Raghavan, 'Public library service in Tamil Nadu: a situation report', Seminar on Public Library Services and Information Networks: Papers and Proceedings, Madras: Madras Library Association (1988) pp. 41-72.

8. M. Krishna Murthy. 'Survey of branches and service centres under City Central Library, Jayanagar, Banagalore: a sample study of collection and users', M.S. dissertation, Bangalore: Department of Library and Information Science, Bangalore University (1989).

9. P. Sankaralingam and K.S. Raghavan, 'Public library service in Tamil Nadu: a situation report', p. 65.

10. In Chikmagalur District, 70 percent of males and 50 percent of females were literate, 80 percent of workers were employed in agriculture or related activities. Here the first public library was established only in 1971, and although progress was rapid thereafter (by 1995 there were also ten branch libraries, seven book delivery stations and thirtynine village assembly libraries), 96 percent of the district's villages had no library provision and there were 17,635 members out of a population of 1,017,283 (1.7 percent). See K.C. Ramakrishna Gowda, 'Nature of public library 
services in relation to users and their needs: a study of public libraries in Chikinagalur District (Karnataka)', Ph.D. dissertation, Department of Studies in Library and Information Systems, University of Mysore (1995) pp. 86, 103, 110, 138.

11. Approximately 65 percent of the total book resources in the Chikinagalur library system were Kannada literature, although there was not a single Kannada subject journal (Ibid., p. 225).

12. These included art and book exhibitions, discussions or lectures on topics of local interest, educational and awardwinning films, programs on 'national integration', and exhibitions on science and technology (Ibid., pp. 200-13, 224, 256).

13. Because the profile of the user population could change during the course of the day or during the week, administration of questionnaires occurred on a regular basis during five time blocks daily and on each day of the week. The result of these efforts was a roughly equivalent number of responses from each time block and from each day of the week. The survey occurred when there were no major religious festivals or public holidays that affected patronage of the facilities. The authors were personally involved in presentation of questionnaires to users in the west zone and part-time in the east zone. Most of the time, after preliminary briefings, staff working at the libraries solicited the participation of patrons and administering the questionnaires.

14. The zone recording the highest percentage of students (50 percent) was the south, where the 1989 study (see above) found that 56 percent of its members were students. It is possible that students gravitated to this library because, as the former center of the city library system, its research collection was more extensive than those of the other zonal libraries. Its collection of materials for preparatory examinations was also the largest among the zonal libraries.

15 . We may contrast the relatively small percentage of housewife respondents with the study of the south zone (see above) that revealed 12 percent of registered members as housewives. It appears that the large number of walk-in clients during the course of the day, with a different gender profile, statistically swamps the registered membership.

16. Peculiarities of the response pattern to the questionnaire challenge the validity of these data on family size. The English form was worded only to capture children going to school, so infants might not appear. But even on the Kannada form, which included separate lines for number of children and number of school-age children, the vast majority of even married persons left this section empty. Queries in this direction seemed to strike users as too personal or too distant from the purposes of the survey, and they were apparently reluctant to volunteer such information.

17. A locational bias may exist in these data, based on the places where questionnaires were distributed in the libraries. In the east zone, the questionnaires stayed at the check-out desk in the back room next to the novels section, and here the majority of users ( 59 percent) indicated that novels were the most important section. In the central zone, the questionnaires rested at a desk near the front of the building next to the periodicals reading section, and here responses indicated that periodicals were the most important goal (67 percent).

18. Among the general English responses were the following: 'Better supervision to prevent tear off from magazine pages earnestly requested. And culprits indulging in such activities punished, promptly'; 'They need control and supervision over the readers. Newspapers \& magazines should not be removed from the stand by readers. . . . Pilferage must be detected and avoided. Silence must be maintained. No loud talking. Discipline must be maintained.'

19. The monthly subscription rate for a single periodical in 1995 was in the range of INR 100-150 (USD 3-5), while the majority of readers at the libraries had monthly household incomes of less than INR 3000 (less than USD 100).

20. Many thanks to the Director of the State Department of Public Libraries, T. Mallesappa, and to the staff of the State Central Library, who gave access to the system and discussed its features with Heitzman on 17 August 1999.

\section{Abstract}

This article describes the development of the public library system in the state of Karnataka, India, several exercises in its evaluation during the mid-1990s, and the current direction of its planning. After outlining the system in the rural district of Chickmagalur, it concentrates on the system in the city of Bangalore, the state capital and India's 'Silicon Valley'. Quantitative and qualitative survey data portray the demographics of library clientele, their information needs, their rating of library materials, facilities and personnel, and the relationship between their evaluations and the preliminary stages of automation. Analysis focuses on issues of age, gender, trajectories of career development, and the rural-urban divide in determining the future planning of the system.

James Heitzman is an Associate Professor in the College of Arts and Sciences, Georgia State University, PO Box 4117, Atlanta, GA 30302-4117, USA. Tel: +1-(404)-651-2250; Fax: +1-(404)-651-1745; Email: jheitzman@gsu.edu

A.Y. Asundi is a Professor in the Department of Library and Information Science, Bangalore University, Bangalore 560056, India. Email: asundi@giasbga.vsnl.net.in 


\section{MORE ON LIBRARIES IN KARNATAKA}

\section{Neglect of structural comforts in libraries.}

L. Aswath. Malaysian Journal of Library E Information Science, 4 (1) Jul 1999, pp. 95-101. tbls. refs.

Examines the planning and utilization of space for different functions in three University Grants Commission (UGC) financed university libraries, located in Karnataka State, India: Bangalore University, Karnatak University and Mysore University. Analyses the planning aspects on the basis of recommendations made by the UGC and standards provided by the Indian Standards Institution (ISI). Findings indicate that the planners have not given due thought to the application of ISI standards and UGC recommendations made for different types of buildings resulting in wastage of space.

\section{Rural libraries in Karnataka.}

B.S. Biradar. Library Science with a Slant to Documentation and Information Studies, 36 (1) Mar 1999, pp. 35-41. tbls. refs.

Describes the library situation in some rural parts of Karnataka, India. Describes the collection sizes, services, staff, buildings and furniture. Suggests remedies for improvement, notably in holdings of agriculture related materials.

The public library service in Bangalore.

A.Y. Asundi, J. Heitzman. Library Science with a Slant to Documentation and Information Studies, 36 (2) Jun 1999, pp .83102. tbls. refs.

Discusses the condition of public libraries in Bangalore, Karnataka, India, during the 1990s and their position within the larger context of the city's urbanization. Describes the client population reached by the services and assesses the ability of the library system to provide relevant sources and services. The methodology, based on user evaluation, directly addresses the problem of client involvement in library system development. The findings suggest directions for the management of change in the Bangalore library and information systems.

(From Library and Information Science Abstracts) 